\title{
Impact of Audit Firm Rotation on Audit Quality: Evidence from Bhutan
}

\author{
Kriti Bhaswar Singh, Abhishek Singh
}

\begin{abstract}
This research study examines the effects of audit firm rotation on audit quality for non-financial public listed companies in Bhutan. Currently, Bhutan has only 21 companies listed on the Royal Securities Exchange of Bhutan Limited (RSEBL). Secondary data obtained for the period of 10 years, between 2009 to 2018, were analyzed using regression analysis. Abnormal Working Capitals Accruals (AWCA) has been used as proxy for audit quality. The study concludes that audit firm rotation has an insignificant but positive relation with AWCA. Thus, in Bhutan audit firm rotation does not affect audit quality for non-financial public companies, which are in tune with prior studies. Further, it was observed that there is an insignificant relation between $A W C A$ and all control variables with the exception of growth. Growth has a decreasing trend at the rate of -0.13 percent while the trend analysis of $A W C A$ shows that audit quality of non-financial public listed companies has been increasing at the rate of 21.01 percent which is an indirect evidence of low audit quality.
\end{abstract}

Keywords : Audit Firm Rotation, Audit Quality, Auditor Independence, Abnormal Working Capitals Accruals

\section{INTRODUCTION}

The collapse of giant corporations such as Enron and WorldCom, during early 2000, raised doubts in the minds of investors about the credibility and usefulness of financial reports. It also raised questions on the ability and the independence of the external auditors who audit the financial statements of the companies and provide their audit opinion on whether the financial statements give 'true and fair' view of the management's financial assertions. In order to protect the investors from such situations in future and to restore the confidence in the financial reporting, the Federal Government of United States approved the Sarbanes- Oxley (SOX) Act in 2002. The main goal of the SOX Act was to 'protect investors by improving the accuracy and reliability of corporate disclosures made in pursuant to the Securities laws' (Senate and House of Representatives of the United States of America, 2002, p. 745). The SOX Act created The Public Company Accounting Oversight Board (PCAOB) in order to restore confidence in independent audit reports and to protect investor's interest. PCAOB has the responsibility to inspect public accounting firms and has the authority to investigate and discipline registered public accounting firms for non-compliance with the SOX Act's regulations of the General

Revised Manuscript Received on July 22, 2019.

Dr. Kriti Bhaswar Singh, Birla Institute of Technology, Mesra (Noida Campus), (Formerly Colombo Plan Faculty (MEA, GoI) to Royal University of Bhutan)

Dr. Abhishek Singh, Birla Institute of Technology, Mesra (Noida Campus)
Accounting Office (GAO).

To curb the problems of independence, SOX-Act mandated the GAO of the United States to examine the potential effects of mandatory rotation of audit firms registered under the Act in the year 2003. It found that mandatory audit firm rotation may not be the most efficient means to improve the auditor's independence thus, it was decided in USA that only the lead partners will be rotated after every five years to safeguard auditor's independence.

In the year 2008, when the world faced the worst global financial crisis, its aftermath re-opened the discussion for mandatory audit firm rotation. In October 2010, European Commission (EC) issued its Green Paper to examine mandatory audit firm rotation to improve independence of auditor. It stated in its proposal that, the regulation introduces mandatory rotation of audit firm after a maximum period of six years that may, under certain exceptional circumstances, be extended to 8 years, to address the threat of familiarity resulting from appointing and reappointing the same audit firm for decades (European Commission, 2011).

In the UK, discussion on the requirement of mandatory rotation of audit firms of Financial Times Stock Exchange listed three hundred fifty companies was suggested to improve the audit quality by the House of Lords Select Committee on Economic Affairs in 2011. However, this suggestion was non-acceptable in the year 2013 due to insufficient empirical evidence. The committee instead proposed requirement that audit committees of UK listed companies to place their audits up for tender after 10 years.

There are many countries that believe mandatory rotation of audit firm is one of the most effective measures to enhance auditor independence and improve audit quality. These countries are: Bangladesh, China, India (for banks), Pakistan, Singapore, South Korea, Thailand, Brazil, Mongolia, Costa Rica, Oman, Paraguay, Serbia, Tunisia, Indonesia, Italy, Bahrain, Australia, Saudi Arabia, Turkey, Austria, Uzbekistan, Spain, and South Africa (Said \& Khasharmeh, 2014; Siregar, Amarullah, Wibowo, \& Anggraita, 2012; Jackson \& Roebuck, 2008).

In the context of Bhutanese entities, the mandatory audit firm rotation was effective since July 18, 2000. The Companies Act of Kingdom of Bhutan (CAKB), 2000 requires the audit firms that are empaneled by the Royal Audit Authority (RAA) to rotate every three years. The establishment of audit system in Bhutan dates to as early as 1961 . The Royal Government issued the

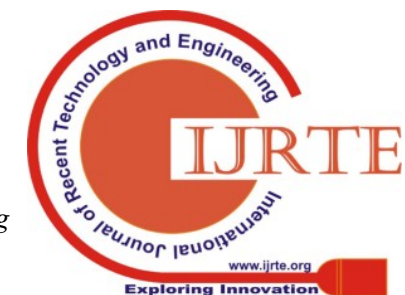


first edition of the Financial Manual in 1963, which was administered by the accounts and audit unit under development wing of the government. The accounts and audit organizations were made responsible to maintain the books of accounts, conduct budgetary controls of revenue and expenditure and undertake periodic audit and inspections of accounts and records.

Later in October 1969, 31st National Assembly voted for the appointment of Royal Auditors to conduct audit of accounts and records of the Royal Government. On April 16, 1970 Royal Audit Department was created with primary responsibility of auditing accounts of the Ministry of Finance, other ministries, Royal Bhutan Army, Royal Bhutan Police and His Majesty's Secretariat. In 1985 the audit service was restructured as an autonomous entity and named RAA. In the year 1989, General Auditing Rules and Regulations (GARR) were issued defining properly the role and responsibilities of RAA.

\section{LITERATURE REVIEW}

In this section we review the extant literature in the field of audit firm rotation and audit quality. The review is grouped into as key concepts of auditing, audit quality, auditor independence, and auditor rotation in the following paragraph. In continuation to the above, the arguments of the proponents and opponents of audit firm rotation have also been reviewed. Furthermore, prior literature on the relationship between audit quality and audit firm rotation has been examined.

The International Auditing Practices Committee defines auditing as 'the independent examination of financial information of any entity, whether profit oriented or not, and irrespective of size, or legal form, when such examination is conducted with a view to expressing an opinion thereon'.

Audit quality has been defined by many scholars over the past few decades. Despite the fact, the definition given by DeAngelo (1981) has been a well-known and widely accepted. She states that, 'The quality of audit services is defined to be the market assessed joint probability that a given auditor will be both (a) discover a breach in the client's accounting system, and (b) report the breach.' In another word, the quality of the audit will depend on the probability that an auditor discovers material misstatement in the financial statements prepared by the company management and reports the same without any manipulation.

Audit failure can occur either when Generally Accepted Accounting Principles (GAAP) were not applied by the auditor, or when an auditor fails to issue a qualified audit report in situations that demand such a report (Francis, 2004). In both the above cases, the audited financial statements will mislead the users of the same.

The concept of audit and independence are the twin side of the same coin, as stated by the research committee of the Institute of Chartered Accountants of India, 'professional integrity and independence is an essential characteristic of learned professions, but more so in the case of the accounting profession. Independence implies that the judgment of the person is not subordinate to the wishes or directions of another person who might have engaged him or to-his own self-interest.' Tepalagul \& Lin (2015) argues that there are four main threats to auditor independence which are client importance, non- audit services, auditor tenure, and client affiliation with audit firms.

A study on client's importance by Hope \& Langli (2010) concluded that auditors who receive higher audit fees are highly likely to issue a modified audit report. Although, there is limited evidence in support of the claim, the argument that Big 4 audit firms tend to be more conservative in the process of auditing large clients is supported (Tepalagul \& Lin, 2015). In another study Frankel, Johnson, \& Nelson (2002) concludes that there is some evidence which suggests that audit quality may be impaired when auditors provide non-audit services to the same client. In addition, SOX Act prohibits an auditor from providing non-audit services to client to whom they are statutory auditor.

Prior literature has examined the relationship between auditor tenure and auditor independence have yielded mixed result. It is argued that longer audit tenure may results in an auditor to report in favor of the client. However, several scholars argue that longer audit-client tenure will increase the auditor's understanding of the client's business which may help increase audit quality.

There has been study to examine the relation between audit size and audit quality. DeAngelo (1981) was one of the first scholars to find evidence which suggest that audit quality depended on the size of the audit firm. Several studies show that Big 4 audit firm (PWC, Ernst and Young, Deloitte, and KPMG) supply higher quality of audit services than smaller audit firms. These studies show evidence that Big 4 firms are sued less often (Palmrose, 1988) and less often receive sanctions by the Security Exchange Commission (Feroz, Park, \& Pastena, 1991). However, it is argued that large audit firms have more resources in order to fight law suits and regulation (Francis, 2004) and therefore the claim that Big 4 firms supply higher audit quality is countered. Becker, DeFond, Jiambalvo, \& Subramanyam (1998) found that the income increasing discretionary accruals, used as audit proxy, for the clients of larger audit firms are relatively lower than that of small audit firm clients showing favorable audit quality for large audit firm. Overall, it can be concluded that, there is substantial evidence in support of the claim that Big 4 audit firms provide higher audit quality than non-Big 4 firms.

Audit firm rotation is defined as the, 'Imposition of a limit on the period of years in which a particular registered public accounting firm may be the auditor of record for a particular issuer' (Senate and House of Representatives of the United States of America, 2002, p. 775). One of the main reasons to rotate auditors to enhance auditor independence and eventually audit quality assumes that by 
rotating auditors, excessive familiarity between the auditor and its auditee will be reduced and it will reinforce the auditors' professional skepticism and independence in reporting material misstatement (Ebimobowei \& Keretu, 2011). Auditor rotation can either be at the partner level or at the firm level (Chen, Lin, \& Lin, 2008). The current regulation as stipulated in the CAKB, 2000 and Companies Act of Bhutan (CAB), 2016 requires companies to appoint auditors after every three consecutive financial years. Bhutan's audit rotation practice is at the firm level. Due to the subject of audit firm rotation being relevant as a result of newly adopted regulation, this paper focuses on this level of auditor rotation in order to examine whether the audit firm rotation measure is effective in achieving its intended goal.

Proponents of audit firm rotation mostly argue upon the assumption that long audit tenure may cause relationship to be established between the auditor and the auditee, which in turn possibly impairs the auditors' independence and objectivity (Cameran, Prencipe, \& Trombetta, 2014). When auditor independence is impaired due to the familiarity bonding between auditor and auditee any discovered breaches in the financial statements may less likely be reported (DeAngelo, 1981). To avoid such undesirable scenario, it would be beneficial if there is a fixed term on the period in which one audit firm may be appointed to the same client in order to enhance auditor independence (Cameran et.al.,2014). This claim is supported by Barbadillo \& Okpala (2011) who found evidence suggesting that longer audit firm tenure can result in compromised auditor independence.

On contrary, opponents of audit firm rotation argue on the grounds that audit firm rotation causes loss of client specific knowledge when one audit firm is forced to resign from providing the audit services resulting in low audit quality (Jackson \& Roebuck, 2008). As a result of the loss of client specific knowledge, audit firm rotation requires new audit firms to gain knowledge on the client's business which incurs additional cost for the client. According to GAO report, 2003, it is estimated that for most Fortune 1000 companies that total additional costs incurred for auditor selection process and additional auditor support are at least $17 \%$ of the audit fees of the initial year of engagement. Studies have also proved that audit firm rotation has negative effect on audit quality. For an instance, Jackson \& Roebuck (2008) found evidence supporting this claim by concluding that there is minimal benefits of audit firm rotation on audit quality in Australian context.

Following the adoption of the audit firm rotation many countries have also studied on the relationship between audit quality and audit firm rotation. The researchers around the globe have used different proxies for audit quality in order to draw insights between audit quality and audit firm rotation. A study carried out in Bahrain, where audit firm rotation happens every 5 years, in the year 2014 focused on finding out the effects of mandatory audit firm rotation on auditor independence (proxy for audit quality). It was found out that there is a significant relationship between mandatory audit firm rotation and auditor independence at 5\% significance level (Said \& Khasharmeh, 2014).

Similarly, in the year 2015, a study examined the relationship between rotation policy, audit firm specialization and audit quality in the government audit market firm of Florida. The study used total number of incidents of non-compliance with accounting and auditing standards as a proxy for audit quality. The study concludes that there is a significant positive sign that rotation policy increases the probability of compliance with reporting and auditing standards (Elder, Lowensohn, \& Reck, 2015).

In line with the above a study on mandatory firm rotation and audit quality in South Korea provides additional evidence on the effectives of mandatory audit firm rotation. The study was carried out in the year 2015 for 8889 non-financial institution listed on Korean Stock Exchange from 2006 to 2010 . It is mandatory to rotate the audit firm every 6 years in South Korea. The study used going concern audit opinion as a proxy for audit quality and run multiple regression model, Pearson and Spearman rank correlation (Kim, Lee, \& Lee, 2015).

Correspondingly, a study in Italy used Abnormal Working Capital Accruals as a proxy for audit quality to study the association between mandatory audit firm rotation and audit quality. The audit firms in Italy are required to rotate every 3 years. The study examined 1184 non-financial Italian listed companies for the period of 20 years (1985 to 2004). After carrying out multiple regression and t-test analysis, it was found out that audit quality tends to improve only in the last engagement year of the audit period (Cameran, Prencipe, \& Trombetta, 2014).

However, a study in the context of Australia conducted in the year 2008 for 1750 Australian listed firms from the year 1995 to 2003 states otherwise. The study adopted propensity to issue a going concern report and levels of discretionary accruals in place of audit quality. The study concluded that there is minimal benefits of mandatory audit firm rotation on to Australian firms i.e. mandatory audit firm rotation do not improve audit quality (Jackson \& Roebuck, 2008).

In the year 2011 a study was conducted in China taking modified audit opinion as proxy for audit quality. Audit firms in China rotated every 5 years. The study took 8560 firms from 1997 to 2005 to examine the association between different audit rotations on audit quality. This study concluded that mandatory audit partner rotation is associated with a significant higher likelihood of receiving a modified audit opinion than no rotation group. (Firth, Rui, \& Wu, 2011).

Summarizing the review of the prior literature on relationship between audit firm rotation and audit quality, it is clear that rotating audit firm can have both favorable and less favorable effects. In the context to Bhutan, there is no such studies till date aiming at finding out 
the effects of audit firm rotation on audit quality for companies incorporated in Bhutan.

Based on the previous studies, the following hypothesis is developed to be tested in this study.

H0: Audit firm rotation does not affect audit quality for non-financial public listed companies of Bhutan.

H1: Audit firm rotation affects audit quality for non-financial public listed companies of Bhutan.

The next section outlines the research methodology that was adopted to test the hypothesis.

\section{RESULT AND DESICCATION}

It is evident from the review of literature that audit firm rotation is crucial from the perspective of providing true and fair view of financial position of the company and for the financial statement on which investors rely upon. The audit policy of audit firm rotation has existed in Bhutan since the enactment of CAKB 2000. However, no research in this area has been carried out in Bhutan. The current study is aims at filling up this research gap by examining the effects of audit firm rotation on audit quality for the public listed companies. Further it aims to find if there is any relationship between audit firm rotation and audit quality.

Companies listed on the stock exchange was initially taken as sample. Public listed companies were chosen because of the fact that the list of private companies is not accessible in Bhutan. Currently, Bhutan has only 21 companies listed on the Royal Securities Exchange of Bhutan Limited (RSEBL). However, from the list six financial companies (bank and insurance), due to their different asset base and financial structure were excluded. While computing Abnormal Working Capital Accruals (AWCA), which is used as a proxy for audit quality in this study, the difference in structure of financial firm will yield unrepresentative results. Therefore remaining 15 non- financial public listed companies, comprising $71 \%$ of listed companies, were taken as final sample.

Secondary data such as annual reports of the companies, filing with the stock exchange and tax authority were obtained for a period of 10 years, that is from 2009 to 2018. The period was so chosen because new regulation on audit policy was effective in the year 2003 with the issuance of CAKB 2000 making the subject relevant.

Correlation and regression analysis were used to analyze the empirical data with a view to measure the effects of audit firm rotation on audit quality by using the amount of AWCA as a proxy for audit quality. Regression analysis allows the researchers to predict the value of the dependent variable (audit quality, measured as the amount of AWCA) based upon the beta value of independent variable/s (audit firm rotation) and also to determine whether audit quality has increased, decreased, or remained unchanged after an audit firm rotation has taken place.

The concept of Abnormal Working Capital (AWC) can be understood as AWCA. Working capital is the change in non-cash working capital accounts such as, inventories, accounts receivable and accrued expenses (Defond \& Park, 2001). The amount of AWCA is the difference between the realized working capital and an expected level of working capital that is required to support the current sales level (Carey \& Simnett, 2006). It is argued that a large amount of AWCA is an indirect evidence of lower earning quality and thus also lower audit quality (Francis \& Yu, 2009).

The amount of AWCA has been computed as following: $\mathrm{AWCAt}=\mathrm{WCt}-(\mathrm{WCt}-1 \div \mathrm{St}-1) * \mathrm{St}$

Where:

$\mathrm{t}=$ the year, $\mathrm{t}-1$ refers to the previous year

$\mathrm{WCt}=$ the non-cash working capital in the current year computed as; (current assets-cash and short term investment) - (current liabilities - short term debts)

$\mathrm{WCt}-1=$ the non-cash working capital in the previous year

$\mathrm{St}=$ the sales in the current year

$\mathrm{St}-1=$ the sales in the previous year

Further, determination of whether audit firm rotation has occurred or not has been done manually by comparing the audit firm responsible for auditing the annual report of the prior year to the auditing firm responsible for auditing the annual reports of current year.

The following control variables, to assure that no other variables other than the variable of interest will influence the result, from prior studies (Jackson et. al., 2008; Carey \& Simnett, 2006), have been used.

a) BIG4; whether s firm's financial statement has been audited by a BIG4 audit firm or not;

b) SIZE; measured in the natural logarithm of total assets;

c) LEVERAGE; measured as the ratio of total liabilities to total assets;

d) RETURNS; measured by the returns on assets, and e) GROWTH; measured by change in sales compared to the prior year, divided by the sales from the prior year. The following regression model has been used to test the effects of audit firm rotation (AR) on audit quality (AQ) $\mathrm{AQ}_{\mathrm{t}}=\mathrm{AR}+\beta_{1} \mathrm{BIG}_{\mathrm{t}}+\beta_{2}$ SIZE $_{\mathrm{t}}+\beta_{3}$ LEVERAGE $_{\mathrm{t}}+$ $\beta_{4}$ RETURNt $+\beta_{5}$ GROWTH

\section{DATA ANALYSIS AND FINDINGS}

In the following section analysis of data for the effect of audit firm rotation on AWCA for non-financial public listed companies in Bhutan and result thereof are presented. The control variable BIG4 has been omitted from the analysis as none of the non-financial

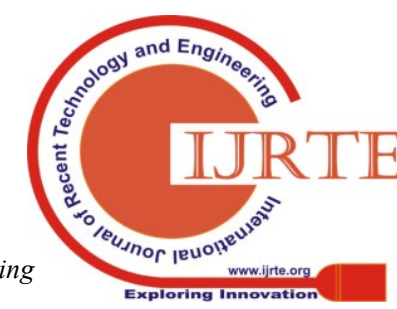


public listed companies are audited by the BIG4 audit firm.

Table 1 shows the regression result of AWCA and Audit Firm Rotation, Table 2 shows the regression result of AWCA and Leverage, Table 3 shows the regression result of AWCA and Return on Assets, Table 4 shows the regression result of AWCA and Growth, Table 5 shows the regression result of AWCA and Size, and Table 6 shows the multiple regression result of AWCA, Audit Firm Rotation, Leverage, Return on Assets, Growth, and Size.

Further the study has also carried out consolidated trend analysis of AWCA and Growth of the Firm for all non-financial public listed companies for 10 years from 2009 to 2018. Growth of the Firms' trend analysis has only been carried out apart from other variables as this particular variable has a significant relationship with AWCA. In addition, trend analysis of AWCA has been carried out to find whether the audit quality for all non-financial public companies has increased, decreased, or remained same over the period of 10 years.

\section{REGRESSION AND CORRELATION RESULTS}

Table 1 Regression Result: AWCA and Audit Firm Rotation

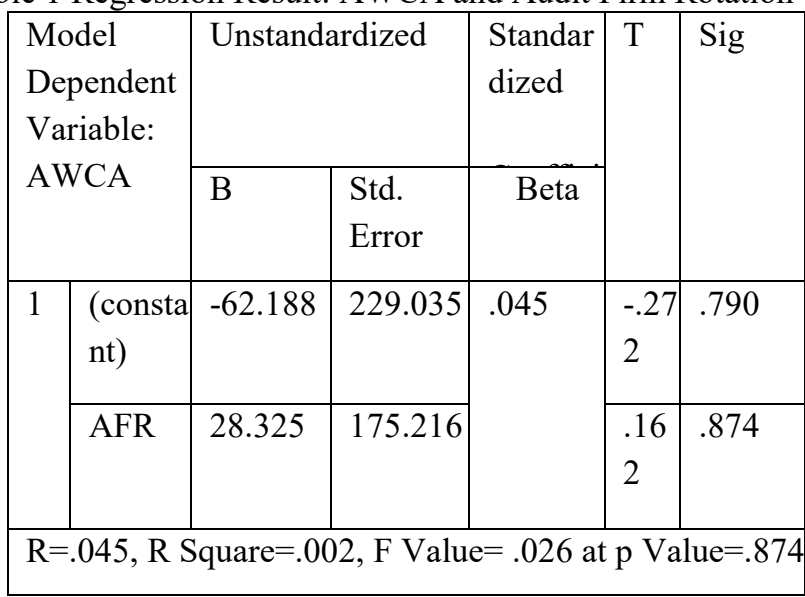

The results of regression analysis, where the dependent variable is AWCA and independent variable is Audit Firm Rotation in Table 1 indicates that there is no significant relationship between AWCA and Audit Firm Rotation (F-ratio of 0.026 and p-value 0.874). Further, R square is insignificantly small at 0.002 which indicates that Audit Firm Rotation explains only 0.2 percent of total variance in the value of AWCA. The remaining 99.8 percent of the total variance in the value of AWCA is due to other factors. Thus, it can be stated that Audit Firm Rotation does not affect AWCA for non-financial public listed companies of Bhutan. The positive sign of the regression coefficient indicates that there is a positive relationship between AWCA and Audit Firm Rotation. Therefore, it can be stated that AWCA has a positive but insignificant relationship with Audit Firm Rotation for non-financial public listed companies in Bhutan.

Table 2 Regression Result: AWCA and Leverage

\begin{tabular}{|c|c|c|c|c|c|c|}
\hline \multicolumn{2}{|c|}{$\begin{array}{l}\text { Model } \\
\text { Dependent } \\
\text { Variable: } \\
\text { AWCA }\end{array}$} & \multicolumn{2}{|c|}{ Unstandardized } & \multirow{2}{*}{$\begin{array}{l}\text { Standard } \\
\text { ized } \\
\text { Coefficie } \\
\text { ntc } \\
\begin{array}{c}\text { B } \\
\text { e }\end{array}\end{array}$} & \multirow[t]{2}{*}{$\mathrm{t}$} & \multirow[t]{2}{*}{ Sig } \\
\hline & & B & $\begin{array}{l}\text { Std. } \\
\text { Error }\end{array}$ & & & \\
\hline \multirow[t]{2}{*}{1} & $\begin{array}{l}\text { (consta } \\
\text { nt) }\end{array}$ & -53.932 & 80.616 & \multirow[t]{2}{*}{.102} & $\begin{array}{l}-.66 \\
9 \\
\end{array}$ & $\begin{array}{l}.51 \\
5 \\
\end{array}$ \\
\hline & $\begin{array}{l}\text { Levera } \\
\text { ge }\end{array}$ & 60.041 & 161.862 & & .371 & $\begin{array}{l}.71 \\
7\end{array}$ \\
\hline
\end{tabular}

The results of regression analysis, of AWCA and Leverage in Table 2 indicates that there is no significant relationship between AWCA and Leverage (F-ratio 0.138 and a p-value 0.717$)$. $R$ square is 0.010 shows that 99 percent of the total variance in the value of AWCA is due to other factors than leverage. The positive sign of regression coefficient indicates that there is a positive relationship between AWCA and leverage. It can be stated that AWCA has a positive but insignificant relationship with Leverage for non-financial public listed companies in Bhutan.

Table 3 Regression Result: AWCA and Return on Assets

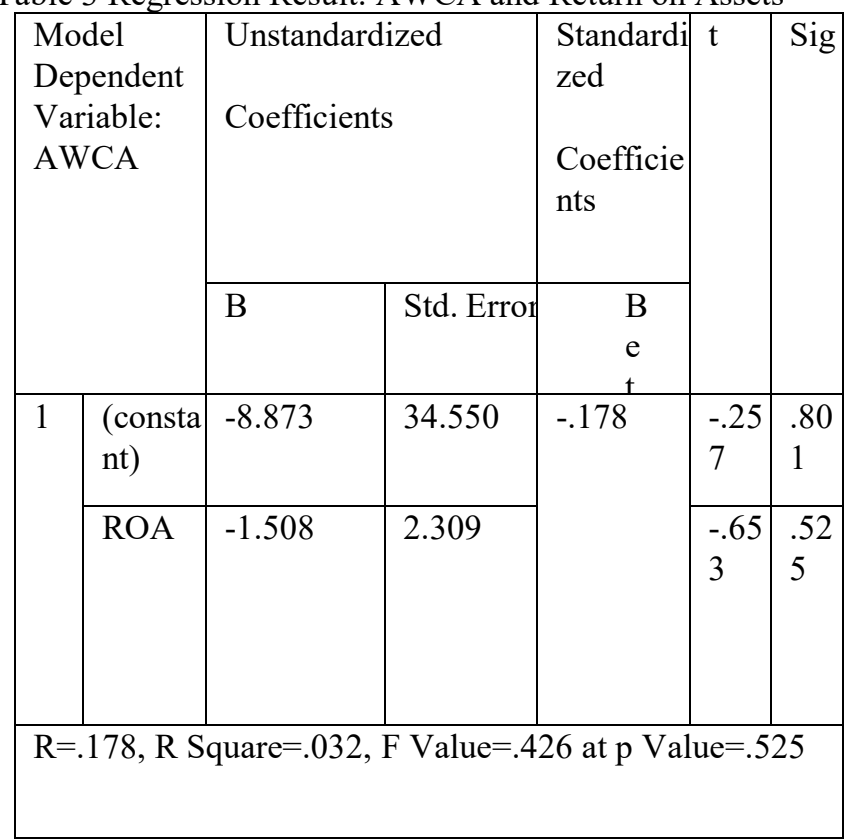

Table 3 shows the results of regression analysis where the dependent variable is AWCA and independent variable is Return on Assets. It can be observed that there is no significant relationship between AWCA and Return on Assets (F-ratio 0.426 and p-value 0.525). A small R-square 0.032 indicates 96.8 percent of the total variance in the value of AWCA is due to other factors than return on asset. Further, negative sign of regression coefficient indicates that there is a negative relationship between AWCA and Return on Assets i.e. when Return on Assets will increase AWCA for non-financial public listed companies in Bhutan will decrease.

Table 4 Regression Result: AWCA and Growth 


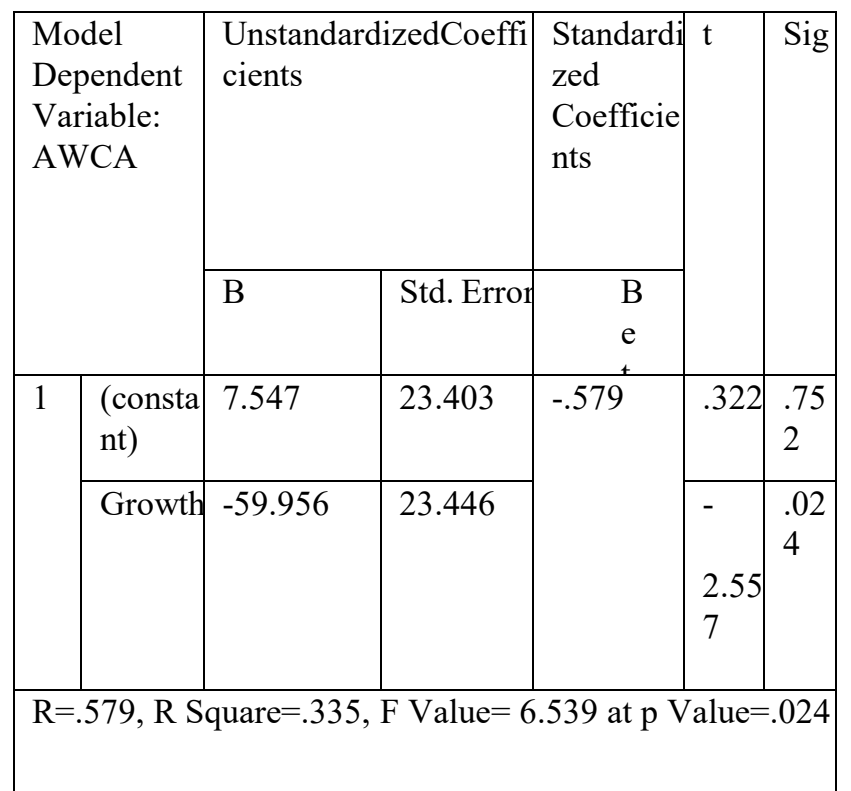

The results of regression analysis between AWCA and Growth is presented in Table 4. It can be observed that there is a significant relationship between AWCA and Growth of the Firm (F-ratio 6.539 and p-value of $0.024)$. $R$ square is 0.335 . It can be concluded that Growth of the Firm has effect on audit quality. The negative sign of regression coefficient indicated that there is a negative relationship between AWCA and Growth of the firm i.e. Growth in the Firm would decrease AWCA and thus audit quality. Therefore, it can be concluded that AWCA has a negative and significant relationship between Growth of the Firm for non-financial public listed companies in Bhutan.

Table 5 Regression Result: AWCA and Size

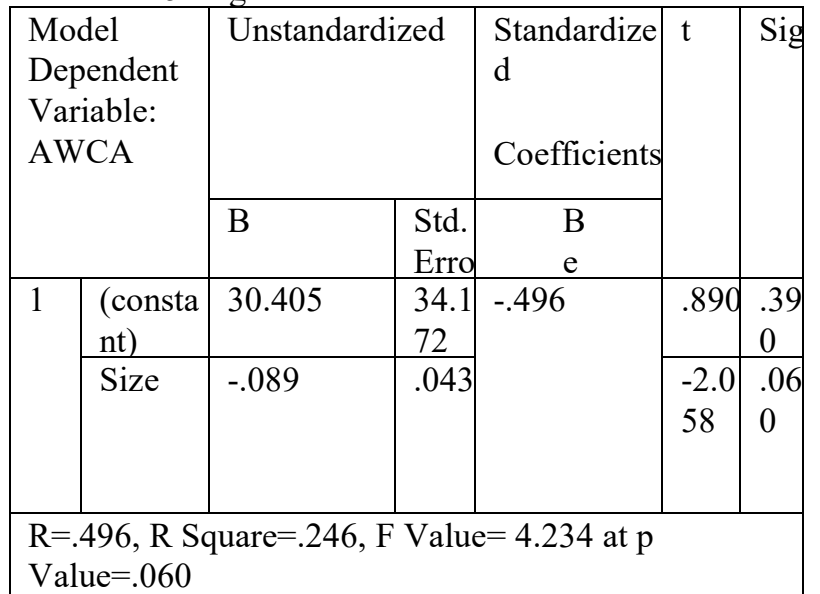

The results of regression analysis between AWCA and Size of the firm in Table 5 indicates that there is no significant relationship between AWCA and Size of the Firm (F-ratio 4.234 and p-value 0.06 ). R square value of 0.246 . Further, negative sign of regression coefficient indicates that there is a negative relationship between AWCA and Size of the firm i.e. with the increase in the size of the firm, AWCA of non-financial public listed companies in Bhutan will decrease thus decreasing audit quality.

Table 6: Multiple Regression Result: AWCA, Audit Firm

Rotation, Leverage, Return on Assets, Growth, and Size

\begin{tabular}{|l|l|l|l|}
\hline Source & $\begin{array}{l}\text { Sum of } \\
\text { Squares } \\
\text { freedom }\end{array}$ & $\begin{array}{l}\text { Degree of } \\
\text { Square }\end{array}$ \\
\hline Model & $\begin{array}{l}61987.315 \\
6\end{array}$ & 5 & 12397.4631 \\
\hline Residual & $\begin{array}{l}49987.699 \\
3\end{array}$ & 9 & 5554.18881 \\
\hline Total & $\begin{array}{l}111975.01 \\
5\end{array}$ & 14 & 7998.21535 \\
\hline
\end{tabular}

$\mathrm{R}=.74, \mathrm{R}$ Square $=.55, \mathrm{~F}$ Value $=2.23$ at $\mathrm{p}$ Value $=.14$. No. of Observations $=15$

The results of multiple regression analysis of 15 observations, where dependent variable is AWCA, independent variable is Audit Firm Rotation, and control variables are Leverage, Return on Assets, Growth of the Firm, and Size of firm is shown in Table 6. It can be observed that there is no significant relationship amongst AWCA, Audit Firm Rotation, Leverage, Return on Assets, Growth of the Firm, and Size of firm (F-ratio 2.23 and p-value of 0.14 ).

The $\mathrm{R}$ square value of 0.55 and multiple $\mathrm{R}$ square is .527 , indicates that Audit Firm Rotation, Leverage, Return on Assets, Growth of the Firm, and Size of firm together explains about $53 \%$ of total variance in the value of AWCA. Therefore, it is concluded that AFR does not affect AWCA and thus audit quality, for non-financial public listed companies in Bhutan.

\section{Result of Test of Hypothesis}

Result of multiple regression analysis presented in Table 6 for the listed companies in Bhutan indicates the p-value of 0.14 (F-ratio 2.23) at 5 percent significance level and therefore null hypothesis is not rejected. It means that audit firm rotation does not affect audit quality for non-financial public listed companies in Bhutan. The result of the study is in tune with the prior studies by Kwon, Lim, \& Simnett (2014); Siregar, Amarullah, Wibowo, \& Anggraita (2012); Onwucheka, Erah, \& Izedonmi (2012); Firth, Rui, \& Wu (2011); Barbadillo, Aguilar, \& Carrera (2009); Jackson \& Roebuck (2008).

Trend Analysis

Table 7: Consolidated Trend Analysis of AWCA and Growth of the Firm

\begin{tabular}{|c|c|c|c|c|}
\hline Year & $\begin{array}{c}\text { AWC } \\
\text { A } \\
(\mathrm{Mn})\end{array}$ & $\begin{array}{c}\text { Trend of } \\
\text { AWCA } \\
(\mathrm{Mn})\end{array}$ & $\begin{array}{l}\text { Growth } \\
\text { of } \\
\text { Firm } \\
(\mathrm{Mn}) \\
\end{array}$ & $\begin{array}{l}\text { Trend of } \\
\text { Growth } \\
\text { of Firm }\end{array}$ \\
\hline 2009 & 0 & 0 & 0.2 & 1.1 \\
\hline 2010 & 26.56 & -152.75 & 0.5 & 1.0 \\
\hline 2011 & $\begin{array}{c}-371.2 \\
9\end{array}$ & -121.71 & 3.6 & 0.8 \\
\hline 2012 & -8.68 & -90.67 & & \\
\hline
\end{tabular}




\begin{tabular}{|c|c|c|c|c|}
\hline 2013 & 42.89 & -59.64 & 0.1 & 0.6 \\
\hline 2014 & 33.43 & -28.60 & -0.1 & 0.4 \\
\hline 2015 & 24.93 & 2.44 & 0.2 & 0.3 \\
\hline 2016 & -21.83 & 33.47 & 0.1 & 0.2 \\
\hline 2017 & $\begin{array}{c}-832.3 \\
7\end{array}$ & 64.51 & 0.3 & 0.1 \\
\hline 2018 & 848.97 & 95.54 & 0.0 & -0.1 \\
\hline
\end{tabular}

Fig. 1 Consolidated Trend Analysis of AWCA and Growth of the Firm

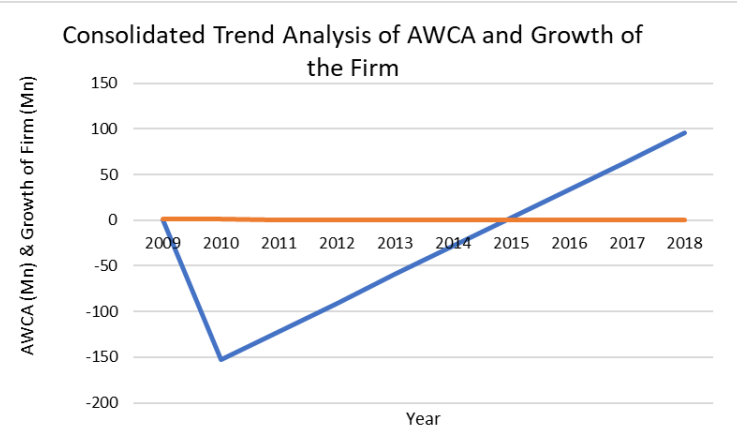

Table 7 and Fig. 1 shows the consolidated trend analysis of AWCA and Growth of firms for non- financial public listed companies for the period 2009 to 2018. AWCA has been increasing for the last nine years (2010-2018) from -152.75 to 95.54 and has therefore, an increasing trend from the year 2010. The rate at which AWCA is increasing is 21.01 percent. This increasing trend indicates that audit quality for all the non-financial public listed companies has been decreasing.

Further, it is observed that Growth of the Firm has decreased from 1.1 in the year 2009 to -0.1 in the year 2018. Thus, it can be stated that Growth of the Firm has a decreasing trend and it is decreasing at the rate of -0.13 percent every year. It can be stated that, AWCA and Growth of the Firm has significant but negative relationship i.e. when AWCA increases, Growth of the Firm will decrease.

\section{CONCLUSION}

The study concludes that Audit Firm Rotation has an insignificant relationship with AWCA and do not affect Audit Quality. Thus, the null hypothesis is not rejected. The possible reason could be that, there are certain instances where non-financial companies in Bhutan have practiced audit partner rotation instead of audit firm rotation. It is also clear from the findings of the study that the relationship between AWCA and all control variables are insignificant except for Growth of the Firm. The trend of AWCA is increasing is 21.01 percent in last 10 years which indicates that audit quality for all the non-financial public listed companies has been decreasing. his may be because of the transition from Generally Accepted Accounting Principles (GAAP) to
Bhutanese Accounting Standards (BAS) in the preparation of financial statements. BAS is in line with International Financial Reporting Standards and it is implemented in Bhutan from the year 2013.

\section{REFERENCES}

1. Barbadillo, E. R., Aguilar, N. G., \& Carrera, N. (2009). Does Mandatory Audit Firm Rotation

2. enhance Auditor Independence? Evidence from Spain. Auditing: A Journal of Practice and Theory, 113-135.

3. Becker, C. L., DeFond, M. L., Jiambalvo, J., \& Subramanyam, K. R. (1998). The effect of audit

4. quality on earnings management. Contemporary Accounting Research, 15(Spring), 1-24.

5. Cameran, M, Prencipe, A., \& Trombetta, M. (2014). Mandatory Audit Firm Rotation and Audit

6. Quality. European Accounting Review, 59(4), 35-58.

7. Carey, P. \& Simnett, R. (2006). Audit partner tenure and audit quality. The Accounting Review,

8. 81(3), 653-676.

9. Catherine, H. S, Choi, A., Lee J \& Wonsuk H. (2016). Audit partner's length of audit experience

10. and audit quality: Evidence from Korea. Asia-Pacific Journal of Accounting \& Economics, Vol 23 (1), 1-20.

11. Chen, C. Y., Lin, C. J., \& Lin, Y. C. (2008). Audit Partner Tenure, Audit Firm Tenure, and

12. Discretionary Accruals: Does Long Audit Tenure Impair Earnings Quality? Contemporary Accounting Research, 25(2), 415-445.

13. DeAngelo, L. E. (1981). Auditor size and audit quality. Journal of Accounting and Economics,

14. 21 (4), 183-199.

15. Dechow, P. M., Sloan, R. G. \& Sweeny, A. P. (1995). Detecting earnings management. The

16. Accounting Review, 70(April), 193-226.

17. Economist. (2004, November 20). Special Report: The Future of Auditing, 71-73. Retrieved from

18. www.economist.com/node/3398724

19. Ebimobowei, A., \& Keretu, O.J. (2011). Mandatory rotation of auditors on audit quality, costs

20. and independence in South Africa. Nigeria: International Business Management, 5(1), 166-172.

21. European Commission. (2011). Proposal for a Regulation of the European Parliament and of the

22. council on specific requirements regarding statutory audits of public entities. Retrieved from http://ec.europe.eu/internal_market/auditing/docs/reform/COM_2011_ 779 en.pdf\& ved $=0 \mathrm{ahUK}$

23. Firth, M., Rui, O. M., \& Wu, X. (2011). How Do Various Forms of Auditor Rotation Affect Audit

24. Quality? Evidence from China. The International Journal of Accounting, 47(1), 109-138.

25. Frankel, R. M., Johnson, M. F., \& Nelson, K. K. (2002). The relation between auditors' fees for

26. non-audit services \& Earnings management. The Accounting Review, Vol II, 71-105.

27. Francis, J. R. (2004). What do we know about audit quality? The British Accounting Review,

28. 36(4), 345-368.

29. Hope, O.K., \& Langli, J.C. (2010). Auditor Independence in a private firm and low litigation risk

30. setting. The Accounting Review, 573-605.

31. Jackson, A. B., \& Roebuck, P. (2008). Mandatory Audit Firm Rotation and Audit Quality.

32. Managerial Auditing Journal, Sp (1), 420-437.

33. Kane, G. D., \& Velury, U. (2002). The role of institutional ownership in the market for auditing

34. services: an empirical investigation. Journal of Business Research, 1-8

35. Kim, H., Lee, H., \& Lee, J. E. (2015). Mandatory Audit Firm Rotation and Audit Quality. The

36. Journal of Applied Business Research, 23-39.

37. Kothari, S. P., Leone, A. J. and Wasley, C. E. (2005). Performance matched discretionary accrual

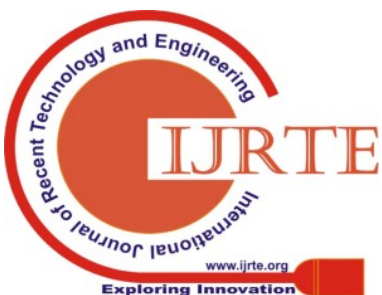


38. measures. Journal of Accounting and Economics, 39(1), 163-197.

39. Kwon, S. Y., Lim, Y., \& Simnett, R. (2014). The Effect of Mandatory Audit Firm Rotation on

40. Audit Quality and Audit Fees: Empirical Evidence from the Korean Audit Market. Auditing: A Journal of Practice \& Theory, 15 (1), 167-196.

41. Onwucheka, J. C., Erah, D. O., \& Izedonmi, F. (2012). Mandatory Audit Rotation and Audit

42. Quality: Survey of Southern Nigeria. Research Journal of Finance and Accounting, Vol-

43. 2, 153-155.

44. Palmrose, Z. V. (1988). An analysis of auditor litigation and audit service quality. Accounting

45. Review, 55-73.

46. Said, K., \& Khasharmeh, H. (2014). Auditors' perceptions on impact of mandatory audit firm

47. rotation on auditor independence-Evidence from Bahrain. Journal of Accounting and Taxation, 13 (2), 1-18.

48. Senate and House of Representatives of the United States of America. (2002). Sarbanes-Oxley

49. Act of 2002. Retrieved from https://www.sec.gov/about/laws/soa2002.pdf\&ved=0ah UKE wj75_7B7ZDVAHXCFJQKHc3MC

50. Siregar, S. V., Amarullah, F., Wibowo, A., \& Anggraita, V. (2012). Audit Tenure, Audit Rotation,

51. and Audit Quality: The case of Indonesia. Asian Journal of Business and Accounting, 3 (1), 55-74.

52. Tepalagul, N., \& Lin, L. (2015). Auditor Independence and Audit Quality a Literature Review.

53. Journal of Accounting, Auditing, \& Finance, Vol-III, 101-121.

54. The Companies Act of the Kingdom of Bhutan 2000. (2000). Retrieved from www.wipo.int /edocs

55. /lexdocs/laws/en/bt/bt013en.pdf.

56. United States General Accounting Office. (2003). Required Study on the Potential Effects of

57. Mandatory Audit Firm Rotation. Retrieved from www.goa.gov/new.items/d04216.pdf. 